\title{
PENGEMBANGAN WEB SEMANTIK SISLILAH KELUARGA KAWITAN PASEK GELGEL DENGAN METODE PENCARIAN FORWARD CHAINING
}

\author{
Komang Adi Wirayasa ${ }^{1}$, I Made Agus Wirawan ${ }^{2}$, I Made Putrama ${ }^{3}$ \\ 1,2,3 Jurusan Pendidikan Teknik Informatika/Universitas Pendidikan Ganesha \\ Singaraja,Bali \\ e-mail : adiwira507@gmail.com ${ }^{1}$, agus.wirawan@undiksha.ac.id ${ }^{2}$, \\ made.putrama@undiksha.ac.id ${ }^{3}$
}

\begin{abstract}
Abstrak
Silsilah kawitan pada dasarnya merupakan sarana bagi masyarakat Hindu untuk menghormati para leluhurnya. Terdapat beberapa silsilah di Bali sehingga jika terdapat suatu aplikasi web yang memerlukan data antar silsilah, maka dibutuhkan suatu skema yang memungkinkan terhubungnya silsilah dari masing - masing sistem tersebut yaitu RDF Schema untuk mendukung penerapan web semantik. Pada proses pencarian menggunakan metode Forward Chaining. Penelitian ini bertujuan: (1) Mengetahui rancangan dan implementasi web silsilah kawitan Pasek Gelgel. (2) Mengetahui respon pengguna web silsilah keluarga kawitan Pasek Gelgel. Penelitian ini diharapkan mampu memberikan informasi tentang kawitan leluhurnya dan keturunan - keturunan selanjutnya. Jenis penelitian ini adalah penelitian dan pengembangan (Research and Development) dengan model penelitian waterfall. Untuk proses pengujian, dilakukan lima (5) jenis pengujian yaitu: (1) uji whitebox (2) uji blackbox (3) uji akurasi metode (4) uji ahli media (5) uji respon pengguna.
\end{abstract}

Kata kunci: Silsilah, RDF, Web Semantik, Pasek Gelgel, Forward Chaining

\begin{abstract}
The genealogy of kawitan is basically a means for Hindu society to honor its ancestors. There are several genealogies in Bali so that if there is a web application that requires cross-genealogical data, then a scheme that enables the linkage of the genealogy of each system is RDF Schema to support the application of semantic web. In the search process using Forward Chaining method. This study aims: (1) Knowing the design and implementation of the web genealogy kawitan Pasek Gelgel. (2) Knowing the user's web response of the family family of kawitan Pasek Gelgel. This research is expected to provide information about the kawitan ancestry and the descendants - the next descendants. This research type is research and development (Research and Development) with waterfall research model. For testing, five (5) test types are performed: (1) whitebox test (2) blackbox test (3) method accuracy test (4) media expert test (5) user response test.
\end{abstract}

Keywords : Ancestry, RDF, Semantic Web, Pasek Gelgel, Forward Chaining 


\section{PENDAHULUAN}

Bali merupakan salah satu provinsi yang ada di Indonesia yang terletak di antara Pulau Jawa dan Pulau Lombok, merupakan sebuah pulau yang sangat terkenal di dunia sebagai tempat yang memiliki kekayaan alam, suku bangsa, dan budaya sehingga hal tersebut telah mengundang sejumlah wisatawan baik lokal maupun mancanegara untuk mengunjungi Pulau Bali. Bali memiliki mayoritas penduduk beragama hindu sehingga Bali dikenal dengan sebutan pulau dewata [1].

Budaya yang khas di Bali dipengaruhi oleh beberpa unsur, salah satunya adalah agama. Ada sloka berbunyi "Moksartham Jagadhita ya ca iti dharmah", yang berarti bahwa tujuan beragama adalah untuk mencapai kesejahteraan jasmani dan ketentraman batin. Tujuan tersebut dapat dicapai salah satunya dengan melakukan pemujaan. Salah satu pemujaan yang dilakukan oleh umat Hindu di Bali adalah pemujaan kepada leluhur atau kawitan.

Banyaknya kawitan di Bali dipengaruhi oleh kondisi sosial dan kedudukan leluhur di masyarakat pada jaman dahulu. Jika leluhurnya pernah menjadi raja, maka keturunannya akan memakai nama kawitan tersebut. Begitu pula jika leluhurnya pernah menjadi wiku, maka keturunannya akan memakai nama kawitannya juga. Penggunaan nama kawitan ini bertujuan untuk mengingatkan seseorang dengan asal-usul leluhurnya, bukan bermaksud untuk membeda-bedakan tetapi lebih kepada menjaga sikap dan perilaku seseorang karena bercermin dengan sikap dan perilaku leluhurnya.

Di antara banyaknya kawitan yang ada, salah satunya adalah kawitan Pasek Gelgel yang merupakan kawitan dengan penganut terbanyak di Bali. kawitan Pasek Gelgel berpusat di Kabupaten Klungkung tepatnya di Desa Gelgel. Banyak orang menganut kawitan ini tapi banyak yang tidak mengetahuinya, oleh sebab itu perlu dilakukan suatu pengembangan guna lebih meningkatkan rasa ingin tahu dan mengenal kawitannya masing - masing.

Berdasarkan hasil wawancara dari Bapak Prof. Drs. Wayan Nurkancana pada 10 Januari 2017, yang merupakan mantan ketua Badan Penelitian dan Pengembangan Maha Gotra Pasek Sanak Sapta Rsi Kabupaten Buleleng Tahun 2001. Beliau mengatakan bahwa banyak laporan dari masyarakat khususnya warga pasek yang mengatakan bahwa mereka sering mengalami musibah seperti kesakitan, tidak tenang, sering bertengkar dengan keluarga. $\mathrm{Hal}$ tersebut dikarenakan mereka melupakan asal usul atau kawitannya. Di samping itu banyak juga yang mengatakan bahwa mereka melupakan siapa saja keluarga dekatnya seperti paman, bibi, kakek, buyut, dll. Beliau juga menambahkan bahwa kawitan itu sangat penting sehingga perlu adanya media informasi yang dapat menjelaskan tentang kawitan itu ke masyarakat luas khususnya masyarakat hindu di Bali.

Banyak faktor yang menyebabkan orang lupa atau tidak tahu kawitannya, yaitu karena tidak adanya dokumentasi silsilah keluarga kawitan Pasek Gelgel secara lengkap yang pengkodumentasiannya masih dalam bentuk babad. Di samping itu faktor perpindahan penduduk membuat semakin renggangnya hubungan antar keluarga. Sebagian besar orang tahu kawitannya hanya dari mendengar cerita dari orang tuanya tanpa tahu dengan jelas garis keturunan dari kawitannya, sehingga lama kelamaan membuat orang lupa dengan kawitannya. Generasi muda yang menjadi pewaris untuk meneruskan garis keturunan kawitannya pun kurang berminat dalam mempelajari sejarah silsilah dari kawitannya, padahal konsep kawitan dibentuk dengan tujuan untuk mempererat hubungan antar keluarga di Bali.

Pada saat ini sedang berkembang teknologi web 3.0 atau yang biasa disebut web semantik. Web semantik merupakan visi masa depan web, dan informasi diberi arti eksplisit, sehingga lebih mudah diproses 
oleh mesin secara otomatis dan lebih mudah menyatukan informasi yang tersedia di web (Koivunen \& Eric, 2001). Pada web semantik menggunakan RDF (Resource Development Framework), yaitu framework yang mendefinisikan resource di dalam web (Seo, 2017). Dengan RDF dapat melakukan pendefinisian suatu data supaya dapat dimengerti oleh komputer sesuai dengan keinginan manusia.

Guna meningkatkan kinerja dari web semantik khususnya pada fungsi pencariannya maka dibutuhkan sebuah algoritma pencarian. Ada banyak metode pencarian yang dapat digunakan, salah satunya adalah Forward Chaining. Forward Chaining merupakan metode dengan pelacakan ke depan yang memulai dari sekumpulan fakta-fakta dengan mencari kaidah yang cocok dengan dugaan/hipotesa yang ada menuju kesimpulan. [2]

Metode Forward Chaining cocok digunakan untuk penelitian ini karena pada penelitian ini mencari hubungan dari user sehingga pencariannya melacak ke depan berdasarkan fakta - fakta misal fakta ayah memiliki saudara serta saudara ayah memiliki anak sehingga mendapat kesimpulan saudara ayah adalah paman dan anak dari paman adalah sepupu.

Berdasarkan masalah tersebut peneliti termotivasi untuk mengembangkan web semantik silsilah keluarga kawitan Pasek Gelgel dengan menggunakan metode pencarian Forward Chaining.

\section{KAJIAN TEORI}

A. Sejarah Kawitan Pasek Gelgel

Dalam buku Babad Pasek karangan Jro Mangku Gde Ketut Soebandi dijelaskan pada jaman dahulu kala, tersebutlah Sang Hyang Pasupati bersemayam di Gunung Himalaya di Jambu Dwipa (India). Beliau mempunyai tujuh putra yang selanjutnya disebut Sapta Bhatara. Ketujuh putra-putra beliau tersebut, beliau utus ke Bali untuk menjadi junjungan orang Bali. Nama-nama ketujuh putra beliau serta tempat parahyangannya di Bali adalah sebagai berikut :

1. Bhatara Hyang Putra Jaya yang juga disebut Bhatara Hyang Mahadewa berparahyangan di Tohlangkir (gunung Agung).

2. Bhatara Hyang Dewi Danuh berparahyangan di hulun danau Batur atau gunung Batur.

3. Bhatara Hyang Gnijaya berparahyangan di gunung Lempuyang.

4. Bhatara Hyang Tumuwuh berparahyangan di gunung Batukaru.

5. Bhatara Hyang Manik Gumawang berparahyangan di gunung Beratan.

6. Bhatara Hyang Manik Galang berparahyangan di Pejeng

7. Bhatara Hyang Tugu berparahyangan di Andakasa.

Lima di antara Sapta Bhatara tersebut tidak mengadakan keturunan, yang mengadakan keturunan adalah Bhatara Hyang Putra Jaya dan Bhatara Hyang Gnijaya. Hyang Gnijaya inilah yang selanjutnya menurunkan keturunan keturunan sampai di I Gusti Pasek Gelgel yang selanjutnya menjadi cikal bakal adanya kawitan Pasek Gelgel di Bali [3].

\section{B. Web Semantik (Web 3.0)}

Web semantik atau web 3.0 merupakan generasi ketiga dari layanan berbasis website. Konsep web 3.0 pertama kali diperkenalkan pada tahun 2001, saat Tim Berners-Lee, penemu World Wide Web, menulis sebuah artikel ilmiah yang menggambarkan web 3.0 sebagai sebuah sarana bagi mesin untuk membaca halamanhalaman web.

Menurut Berners-Lee (2001):

"Web semantik merupakan visi masa depan web, dan informasi diberi arti eksplisit, sehingga lebih mudah diproses oleh mesin secara otomatis dan lebih mudah menyatukan informasi yang tersedia di web. Web semantik adalah perluasan dari web yang mendukung database dalam bentuk yang dapat dibaca oleh mesin." [4]

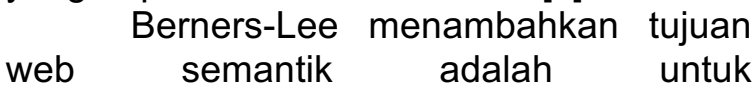
mengembangkan standar dan teknologi yang memungkinkan untuk membantu mesin memahami lebih banyak informasi di web sehingga dapat mendukung penemuan, integrasi data, navigasi, dan otomasi tugas yang lebih kaya. Dengan web semantik, kami 
tidak hanya menerima hasil yang lebih tepat saat mencari informasi, namun juga mengetahui kapan kami dapat mengintegrasikan informasi dari sumber yang berbeda, mengetahui informasi apa yang dapat dibandingkan, dan dapat menyediakan semua jenis layanan otomatis di berbagai domain dari perpustakaan rumah dan digital masa depan ke bisnis elektronik dan layanan kesehatan".

Web semantik tersusun dari berbagai layer seebagai penyusun utama. Layer pendukung teknologi web semantik ditunjukkan pada Gambar 1.

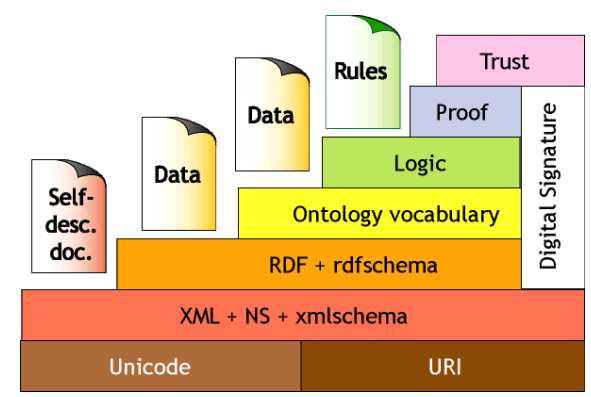

Gambar 1. Semantic Web layer

(Sumber : (W3C, 2013)) [5]

Lapisan - lapisan pada web semantik layer di atas memiliki fungsi masing - masing yaitu :

1. XML, merupakan bahasa framework yang dapat digunakan bersama bahasa pemrograman lain seperti PHP, Java, Ruby, dan lainnya. Digunakan untuk menyimpan serta pertukaran data pada web.

2. $\mathrm{XML}$ schema, digunakan untuk mendifinisikan struktur bahasa XML tertentu.

3. RDF (Resource Description Framework), sebuah bahasa yang memiliki fleksibilitas dalam mendeskripsikan informasi dan metadata.

4. RDF schema, suatu framework yang menyediakan kosakata dasar bagi RDF yang digunakan dalam aplikasi.

5. Ontology, merupakan kosakata yang terdiri dari komposisi dari statementstatement yang mendefinisikan suatu konsep, hubungan dan batasan dari suatu area spesifik dalam lingkup ilmu pengetahuan.
6. Logic and Proof, penalaran logis untuk membangun konsistensi dan kebenaran suatu kumpulan data dan untuk menyimpulkan kesimpulan yang tidak dinyatakan secara eksplisit. Sedangkan untuk pembuktiannya dengan menjelaskan proses dari penalaran logis tersebut.

\section{Resource Description Framework (RDF) dan RDF Schema \\ RDF (Resource Deskription} Framework) menjadi salah satu tulang punggung Web 3.0 adalah format dan spesifikasi yang memungkinkan komunikasi dan interaksi pada level mesin. RDF terdiri dari tiga komposisi, meliputi subject, predicate, dan object. Predicate merupakan komposisi yang menerangkan sudut pandang dari subject yang dijelaskan object, sementara subject dan object merupakan entitas. Object di dalam RDF dapat menjadi subject yang diterangkan oleh object yang lainnya.

Cara kerja RDF dapat diterangkan dengan satu contoh sederhana berikut, untuk mendefinisikan "daun memiliki warna hijau", maka "daun" direpresentasikan sebagai subject, "hijau" merupakan object, dan "memiliki warna" adalah predicate.

RDF Schema adalah vocabulary yang digunakan untuk membuat RDF. Model dari RDFSchema memiliki kemiripan dengan yang digunakan oleh object oriented, yaitu dengan memiliki class, relation, property dan instance. Class adalah kumpulan dari objek yang memiliki kesamaan karakter. Relation adalah sifat hubungan antar kelas. Property adalah karakter dari sebuah kelas. Instances adalah sebuah objek yang sesungguhnya. 'arti' kata menerangkan dalam RDF atau RDFSchema tergantung oleh beberapa faktor, termasuk peraturan sosial, bahasa natural atau penghubung ke dokumen lain. Banyak di antara arti-arti tersebut tidak dapat diakses oleh mesin.

\section{Metode Forward Chaining}

Forward Chaining merupakan metode pencarian yang memulai proses pencarian dari sekumpulan data atau fakta, dari fakta-fakta tersebut dicari suatu 
kesimpulan yang menjadi solusi dari permasalahan yang dihadapi.

Contoh Kasus :

Diketahui sistem pakar dengan aturanaturan sebagai berikut :

R1 : IF suku bunga turun THEN harga obligasi naik

R2 : IF suku bunga naik THEN harga obligasi turun

R3 : IF suku bunga tidak berubah THEN harga obligasi tidak berubah

R4 : IF dolar naik THEN suku bunga turun

R5 : IF dolar turun THEN suku bunga naik

R6 : IF harga obligasi turun THEN beli obligasi

Apabila diketahui bahwa dolar turun, maka untuk memutuskan apakah akan membeli obligasi atau tidak dapat ditunjukkan pada Gambar 2.

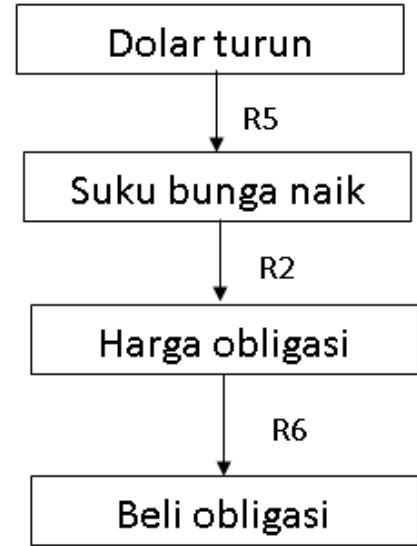

Gambar 2. Skema Forward Chaining

(Sumber : (Arsani, Al', Nyimas, \&

Mardiani, 2013)) [6]

\section{E. Laravel Framework}

Laravel adalah salah satu web application framework yang bersifat open source. Framework ini berjalan di atas PHP 5 dan berbasis MVC (Model View Controller). Laravel pertama kali dirilis pada 22 Februari 2012 dan versi stabil terbaru adalah versi 5.4 yang dirilis pada 24 Januari 2017. Model View Controller adalah sebuah metode untuk membuat sebuah aplikasi dengan memisahkan data (Model) dari tampilan
(View) dan cara bagaimana memprosesnya (Controller). [7]

\section{METODE}

Metode penelitian yang digunakan dalam pengembangan sistem silsilah kawitan Pasek Gelgel adalah menggunakan metode pengembangan perangkat lunak waterfall. Tahapan dalam waterfall mencakup beberapa tahapan diantaranya (1) Requirement Definition (2) system and software design (3 implementation and unit testing (4) integration and system testing dan (5) operation and maintenance. Tahapan metode waterfall dapat dilihat pada Gambar 3.

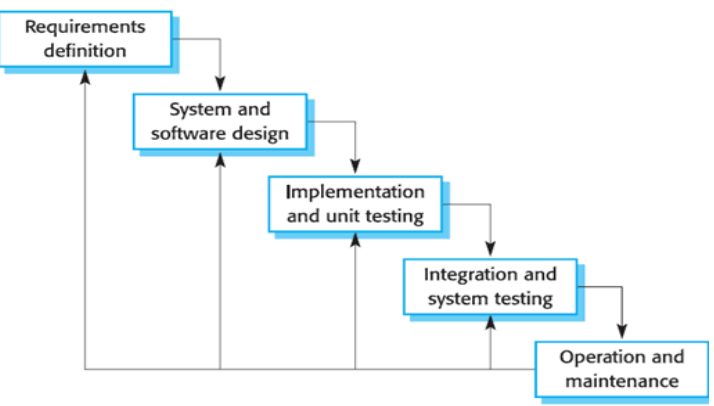

Gambar 3. Tahapan Metode Waterfall (Sumber : Galandi, 2016) [8]

Tahap requirement definition adalah tahap pertama yang dilakukan pengembang sistem untuk mencari dan mengumpulkan kebutuhan secara lengkap. Pada tahap ini pengembang sistem memerlukan komunikasi yang bertujuan untuk memahami perangkat lunak yang diharapkan oleh pengguna dan batasan perangkat lunak tersebut. Informasi ini dapat diperoleh melalui wawancara, diskusi atau survei langsung. Informasi kemudian dianalisis untuk mendapatkan data yang dibutuhkan oleh pengguna seperti kebutuhan pengguna, tujuan pengembangan perangkat lunak dan masukan atau keluaran perangkat lunak.

Tahap system and software design adalah tahap selanjutnya yang dilakukan pengembang sistem dalam menspesifikasi kebutuhan dari tahap sebelumnya dan menghasilkan desain sistem. Desain sistem membantu dalam menentukan perangkat 
keras (hardware) dan sistem persyaratan dan juga membantu dalam mendefinisikan arsitektur sistem secara keseluruhan.

Tahap implementation and unit testing adalah tahap desain sistem dapat dimengerti oleh mesin, dalam hal ini adalah komputer, maka desain sistem tadi harus diubah bentuknya menjadi bentuk yang nyata dan dapat dimengerti oleh mesin, yaitu ke dalam bahasa pemrograman melalui proses coding. Tahap ini merupakan implementasi dari tahap system and software design. Dalam mengimplementasikannya sistem pertama kali dikembangkan di program kecil yang disebut unit, yang terintegrasi dalam tahap selanjutnya. Setiap unit dikembangkan dan diuji untuk fungsionalitas yang disebut sebagai unit testing.

Tahap integration and system testing adalah tahap dari sistem yang dibuat diujicobakan. Semua fungsi - fungsi software harus diujicobakan, agar software bebas dari error, dan hasilnya harus benarbenar sesuai dengan kebutuhan yang sudah didefinisikan. Testing dapat dilakukan dengan melakukan pengujian whitebox, blackbox, uji akurasi metode, uji ahli media dan uji respon pengguna.

Tahap operation and maintenance adalah tahap terakhir dari model waterfall. Pada tahap ini perangkat lunak yang sudah jadi, dijalankan serta dilakukan pemeliharaan. Pemeliharaan termasuk dalam memperbaiki kesalahan yang tidak ditemukan pada langkah sebelumnya atau ada penambahan fitur-fitur yang belum ada pada software pendukungnya dengan software lain yang mebutuhkan upgrading perangkat lunak. Proses ini bergantung pada 2 hal yaitu hubungannya dengan perangkat lunak lain dan permintaan dari pengguna. Sehingga pengembangan diperlukan ketika adanya perubahan dari eksternal perusahaan seperti ketika ada pergantian sistem operasi, atau perangkat lainnya.

\section{HASIL DAN PEMBAHASAN}

A. Implementasi Antarmuka Perangkat Lunak

Tahap pertama yang dilakukan adalah mencari dan mengumpulkan kebutuhan secara lengkap kemudian dianalisis dan didefinisikan yang merupakan bagian dari requirement analysis and definition (analisis kebutuhan dan definisi) pada model tersebut. Pada tahap ini penulis menggali informasi dan mengumpulkan data serta menganalisis secara langsung pengetahuan yang ada pada masyarakat khususnya yang berkaitan dengan silsilah keluarga, salah satunya yaitu silsilah keluarga kawitan Pasek Gelgel. Pada saat melakukan wawancara dengan narasumber sebagaimana tertulis pada pendahuluan, penulis menawarkan usulan solusi yaitu dikembangan suatu sistem silsilah keluarga yang berbasis web semantik di mana sistem tersebut nantinya mengacu pada babad serta buku karangan dari Bapak Wayan Nurkancana yang mengkhusus ke keluarga I Ketut Degug di Br. Kerobokan, Mekarsari, Baturiti, Tabanan yang berjudul "CATUR SARI (Keluarga Besar I Keut Degug)". Selain itu sistem ini juga dapat menjadi pendamping babad karena kedepannya tentu babad tersebut akan sulit untuk dibaca lagi karena tidak semua orang dapat membaca babad tersebut yang menggunakan Bahasa Sansekerta serta umur babad dan keadaan babad tersebut yang tentunya sudah tidak bagus lagi.

Tahap kedua yaitu System and Software Design (sistem dan desain perangkat lunak). Tahap ini memaparkan tahapan awal dari perangkat lunak yang akan dikembangkan, yaitu meliputi kebutuhan perangkat lunak, tujuan pengembangan perangkat lunak, masukan dan keluaran perangkat lunak, dan model fungsional perangkat lunak. Model fungsional perangkat lunak adalah sebagai berikut pada Gambar 4.

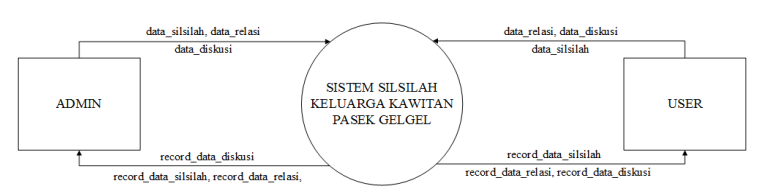

Gambar 4. Diagram Konteks

Diagram konteks merupakan gambaran umum cara kerja sistem dengan 
lingkungan sistem tersebut. Diagram konteks menggambarkan hubungan antara sistem dengan entitas luar yang terlibat dengan sistem serta hubungan masukan dan keluaran.

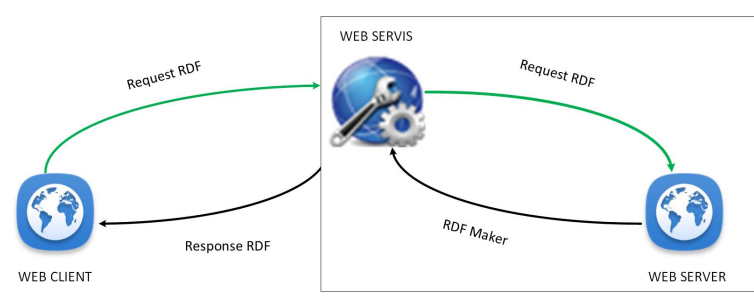

Gambar 5. Rancangan Arsitektur Perangkat Lunak

Terdapat 3 proses utama pada arsitektur di atas, yaitu :

1. Web client melalukan request data RDF melalui web servis yang kemudian web servis meneruskan request ke web server.

2. Web server Membuatkan data RDF yang kemudian diteruskan ke web servis.

3. Web servis memberikan respon berupa data RDF ke web client yang nantinya di web client akan melakukan generate konten dari RDF sehingga bisa dimasukkan ke database.

Tahap ketiga implementation and unit testing, merupakan tahap menimplementasikan rancangan tampilan yang telah dibuat pada tahapan sebelumnya menjadi sebuah perangkat lunak yang telah berfungsi dan dapat digunakan oleh pengguna sesuai dengan fungsi-fungsi yang telah ditetapkan sebelumnya. Adapun implementasi tampilan antarmuka perangkat lunak Web Semantik Silsilah Keluarga Kawitan Pasek Gelgel dengan Metode Pencarian Forward Chaining adalah sebagai berikut.

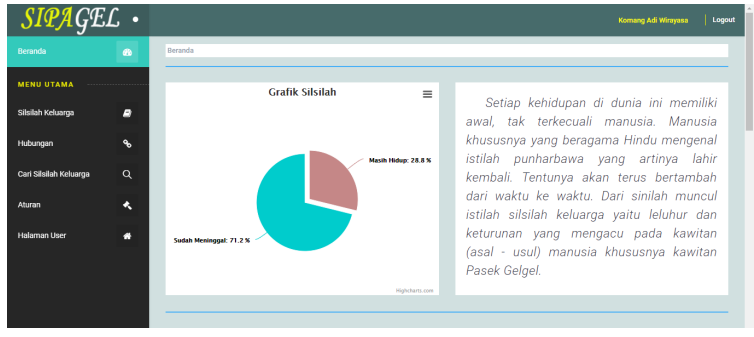

Gambar 6. Tampilan Halaman Administrator

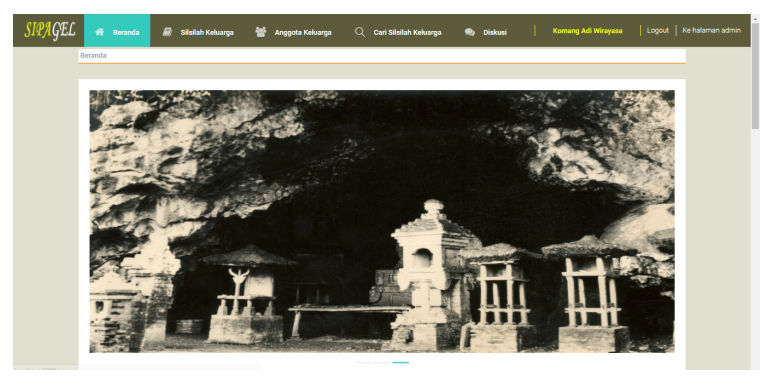

Gambar 7. Tampilan Halaman User

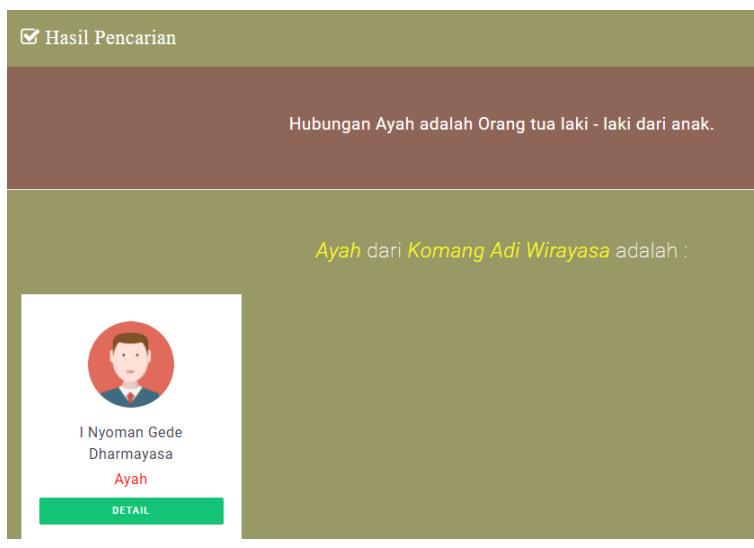

Gambar 8.Tampilan Halaman Pencarian Silsilah

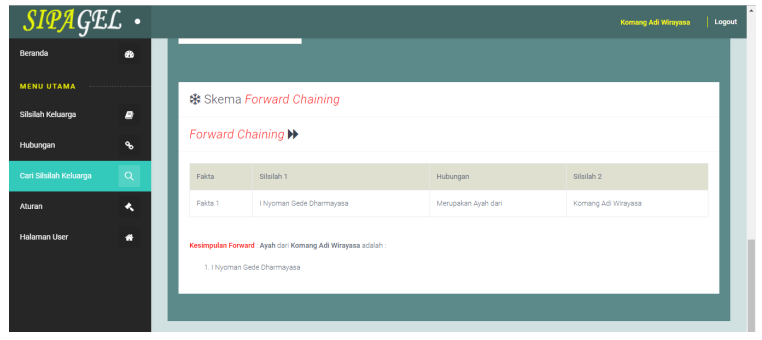

Gambar 9. Tampilan Skema Forward Chaining 


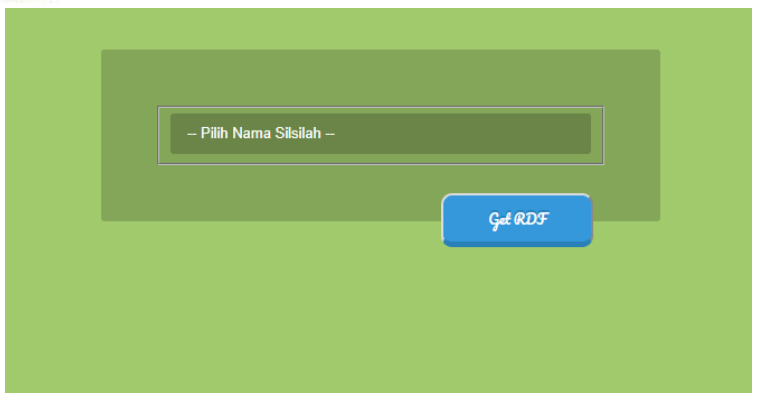

Gambar 10. Tampilan Web Dummy

\begin{tabular}{|c|c|c|c|c|}
\hline $\mathrm{w}_{0} \mathrm{r}$ & - Somere $x_{y y}$ & 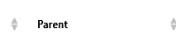 & child & Restian \\
\hline & 102 & Sanglyang pesspati & Putre alag & Anak \\
\hline 2 & 102 & sandyanga pesspati & Denivenun & Anak \\
\hline 3 & 102 & Sandyange pesspati & 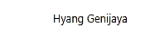 & Anak \\
\hline 4 & 102 & Sanghyang pesspati & Tumounh & Anak \\
\hline 5 & 102 & Sanghyang pespapati & Mank Giaranang g & and \\
\hline 6 & 102 & Sanglyang pesspati & Nank celerg & Ank \\
\hline 7 & 102 & Sanghyang passpati & Togn & ank \\
\hline 8 & 102 & Songlyang pesspati & Nepu Gere & cusu \\
\hline 9 & 102 & Sanglyang Pesspati & Nank cenii & cucu \\
\hline 10 & 102 & Sanghyargy paspati & withatama & curu \\
\hline
\end{tabular}

B. Implementasi Metode Pencarian Forward Chaining dan Pembuatan Skema RDF Silsilah Pasek Gelgel

Dalam pencarian data silsilah sistem melakukan proses pencarian dengan metode forward chaining. Proses pencarian ini memanfaatkan beberapa rule dasar di antaranya (1) Hubungan ayah, (2) Hubungan menikah, dan (3) Hubungan anak. Dari rule tersebut maka akan diperoleh beberapa fakta untuk menarik kesimpulan data silsilah, berikut contoh implementasinya pada Gambar 12.

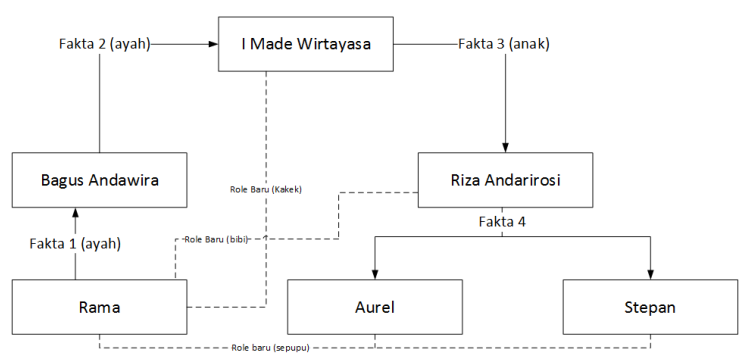

\section{Gambar 12. Implementasi Metode Forward Chaining}

Berikut penjelasan alur pada Gambar 12 di atas.

a. Pertama, ditemukan fakta 1 bahwa Bagus Andawira adalah ayah dari Rama.

b. Kedua, ditemukan fakta 2 bahwa I Made Wirtayasa adalah ayah dari Bagus Andawira.

c. Dari 2 fakta tersebut didapat rule hubungan kakek yaitu I Made Wirtayasa adalah kaket dari Rama.

d. Selanjutnya, ditemukan fakta 3 bahwa Riza Andarirosi adalah anak dari I Made Wirtayasa.

e. Dari 3 fakta tersebut didapat rule hubungan bibi yaitu Riza Andarirosi adalah bibi dari Rama.

f. Kemuadian, ditemukan fakta 4 bahwa Aurel dan Stepan adalah anak dari Riza Andarirosi.

g. Dari 4 fakta tersebut didapat rule hubungan sepupu atau kesimpulan yaitu Aurel dan Stepan adalah sepupu dari Rama.

Dengan kata lain, hubungan sepupu adalah anak dari saudara ayah yang dalam pencariannya harus melewati beberapa rule - rule lainnya.

Setelah pencarian data silsilah berhasil dilakukan, maka hasil pencarian diproses sedemikian rupa ke dalam bentuk skema RDF untuk dapat di-index oleh sistem lain.

Tahapan pembuatan RDF di antaranya:

\section{Tahap 1.}

Pengambilan request data sislilah yang ingin dicari oleh sistem lain. Hasil pencarian selanjutnya dijadikan sebagai namespace, subject, predicate, dan object pada skema RDF. Skema dasar yang diperlukan adalah pada Gambar 13. 


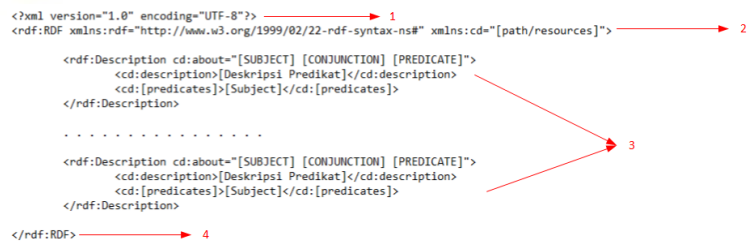

Gambar 13. Skema Dasar RDF

\section{Tahap 2.}

Pembuatan format baku RDF yang dirilis oleh sistem menggunakan simple $\mathrm{XML} / \mathrm{RDF}$ writer. Berikut potongan sumber kode Pembuatan Komponen Subject \& Namespace RDF (dalam hal ini menggunakan kasus dengan predikat ayah).

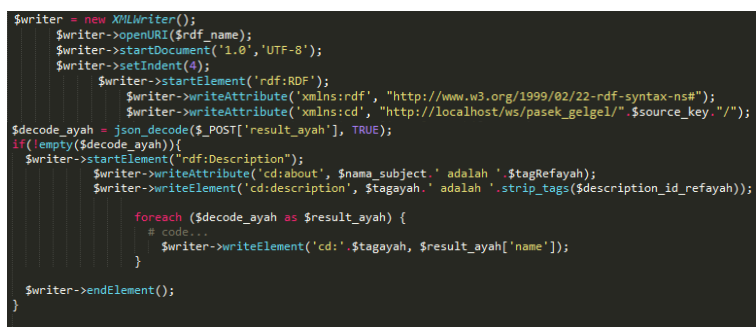

Gambar 15. Kode Sumber Pembuatan Subject dan Namespace

Tahap 3.

Pada tahap ini dilakukan perilisan format RDF untuk di-index oleh sistem lain. RDF yang dirilis memiliki format penamaan [tanggal_rilis]-rdf-

Subject_[nama_subjek].rdf.

Berikut potongan sintak untuk merilis RDF pada Gambar 16.

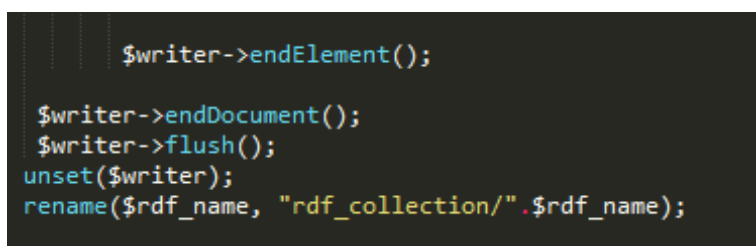

Gambar 16. Potongan Silsilah Perilisan RDF

C. Implementasi Metode Indexing RDF Silsilah Pasek Gelgel

Setelah dilakukan tapat pembuatan RDF, selanjutnya sistem lain akan melakukan proses indexing dengan rangkaian tahapan secara umum sebagai berikut.

\section{Tahap 1.}

Pengambilan context respon RDF dari system. Pada Tahap ini system lain melakukan pembacaan pada tag dasar namespace dan predikat. Berikut sintak yang digunakan untuk indexing RDF ditunjukkan pada Gambar 14.

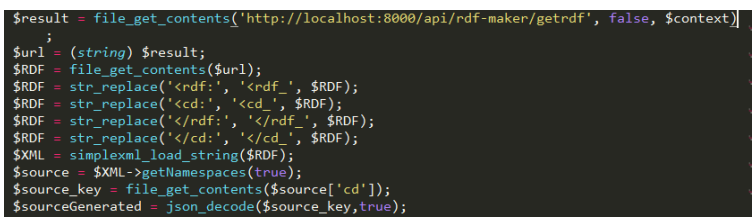

Gambar 14. Sintak Pembacaan Namespace dan Predikat

\section{Tahap 2.}

Pengambilan isi Predikat RDF yang terdapat pada RDF. Pada Tahap ini system lain melakukan pembacaan pada tag deskripsi isi RDF yang memuat beberapa predikat (misal predikat ayah ). Berikut Kutipan sintak yang digunakan untuk indexing isi RDF pada Gambar 17.

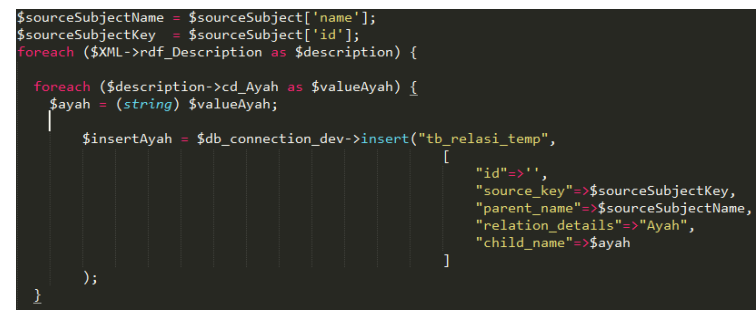

Gambar 17. Sintak Pembacaan Predikat pada Isi RDF

\section{Tahap 3.}

Proses ekstrasi data RDF untuk keperluan memasukkan atau memperbaharui data ke dalam database system lain. Tahap ini berguna untuk mencatat index kunci sumber agar mencegah duplikasi data saat pembacaan RDF berulang kali dalam data yang sama. Berikut sintak yang digunakan untuk memperoleh kunci index untuk mencegah duplikasi adalah pada Gambar 18. 


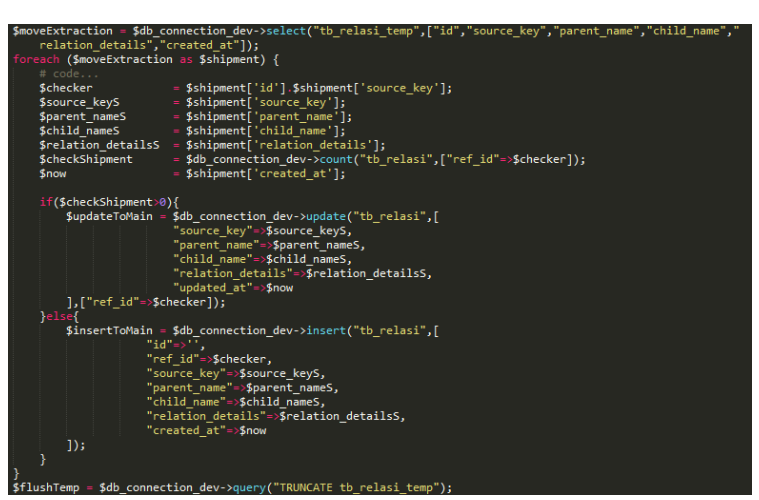

Gambar 18. Sintak Kunci Index

Seluruh tahapan ini merupakan dasar pembacaan format RDF yang dapat dilakukan sistem lain

Tahap keempat yaitu integration and system testing meliputi pengujian yang dilakukan terhadap system. Pada uji respon pengguna menggunakan Pengujian UEQ (User Experience Questionnaire) yang merupakan sebuah metode pengukuran UX. Metode ini menggunakan kuisioner untuk mengumpulkan feedback atau umpan balik dari pengguna ketika menggunakan sebuah produk, penggunaan kuisioner ini karena kuisioner ini dinilai lebih efektif untuk menganalisis. UEQ disusun agar dapat menghasilkan sebuah hasil penelitian atau pengujian secara efektif dan tidak memakan banyak waktu. UEQ berupa kuisioner dengan 26 pertanyaan impresi atas produk yang diberikan kepada user. (Lestari, Santosa, \& Ferdiana, 2016).

Pengujian ini dilakukan dengan melibatkan pengguna yang mana nantinya akan menggunakan sistem secara langsung. Adapun pengguna yang dilibatkan adalah populasi keluarga kawitan Pasek Gelgel sebanyak 10 orang. Hasil dari pengujian ini sebagai bahan evaluasi apakah sistem yang dibuat sudah sesuai dengan kebutuhan pengguna.

Pelaksanaan pengujian UX pada sistem web semantic silsilah keluarga kawitan Pasek Gelgel dilaksanakan pada Senin, 15 Januari 2018. Masing-masing pertanyaan memiliki skala penilaian 1 sampai dengan 7 , yang mana skala tersebut merepresentasikan nilai ke pernyataan sebelah kiri atau ke sebelah kanan. Skala 1 - 3 berarti user lebih setuju dengan pernyataan pada sisi kiri, skala 4 berarti skala atau nilai netral, dan skala $5-7$ berarti user lebih setuju dengan nilai pernyataan di sebelah kanan. Setelah mendapatkan jawaban dari user, selanjutnya ke tahap penghitung yang akan dijabarkan pada Tabel 1.

Tabel 1. Jawaban User

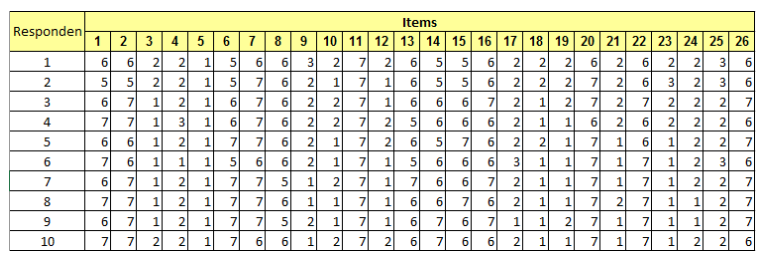

Tabel 1 di atas merupakan data keseluruhan jawaban dari total responden sebanyak 10 orang dengan jawaban masingmasing sebanyak 26 . Selanjutnya jawabanjawaban tersebut dilakukan konversi menjadi bobot nilai jawaban. Secara berurutan berikut ini adalah pasangan skala dan bobotnya: $(1,-3) ;(2,-2) ;(3,-1) ;(4,0) ;(5,1)$; $(6,2) ;(7,3)$ yang disesuaikan dengan posisi nilai negatif dan positif dari masing-masing pernyataan. Jika pernyataan positif berada di sebelah kiri, dan pernyataan negatif berada di sebelah kanan, maka nilai minus menjadi positif. Adapun konversi dari jawaban tabel di atas seperti terlihat pada Tabel 2.

Tabel 2. Konversi nilai Jawaban

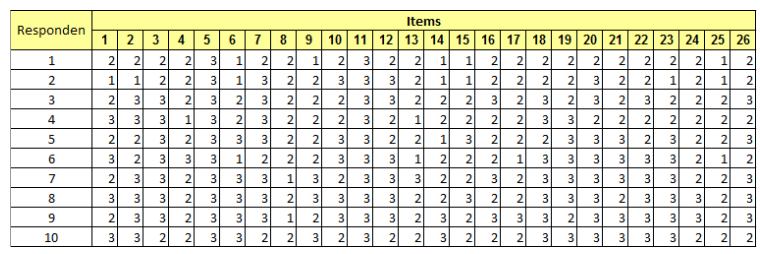

Dari 10 jawaban responden tersebut selanjutnya dilakukan perhitungan mean, varian, dan simpangan baku untuk setiap pertanyaan. Selanjutnya masing-masing pertanyaan diberi kode warna sesuai kelompoknya yakni Daya Tarik (attractiveness), Kejelasan (perspicuity), Efisiensi (efficiency), Ketepatan (dependability), Stimulasi (stimulation), dan Kebaruan (novelty). Hasilnya dapat dilihat pada Tabel 3. 
Tabel 3. Rata-Rata, Varian, dan Simpangan Baku

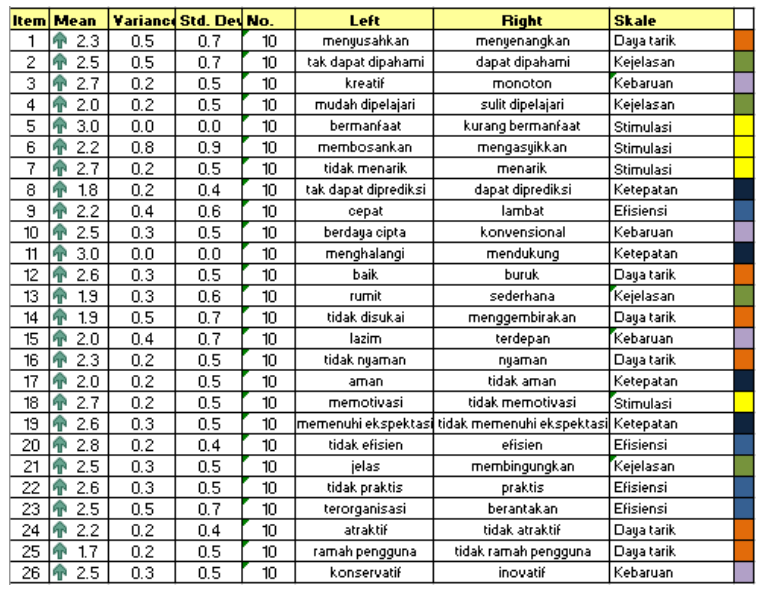

Setelah didapatkan nilai mean dari masing-masing butir pernyataan, selanjutnya dicari nilai varian dan standar deviasi. Nilai varian digunakan untuk mengetahui seberan data terhadap nilai mean. Semakin rendah nilai varian, maka sebaran data mendekati mean, begitu juga sebaliknya. Standar deviasi digunakan untuk mengetahui sebaran data pada sampel. Semakin rendah nilai standar deviasi maka semakin dekat sebaran datanya terhadap mean, begitu juga sebaliknya. Contoh pembahasan pada item 1 dengan detail nilai yaitu : mean $=2.3$; variance $=0.5$; Std. Dev $=0.7$. Dalam hal ini sebaran data pada item 1 dengan mean $=2.3$ menunjukkan tingkat variasi sebaran data mendekati nilai rata rata jawaban item 1, hal ini mengindikasikan data tersebar secara merata atau item 1 memiliki jawaban yang relative sama dari masing - masing responden.

Maka dapat konversi dalam bentuk grafik untuk melihat keseluruhan hasil penilaian responden mendekati nilai positif ataupun nilai negatif seperti pada Gambar 19.

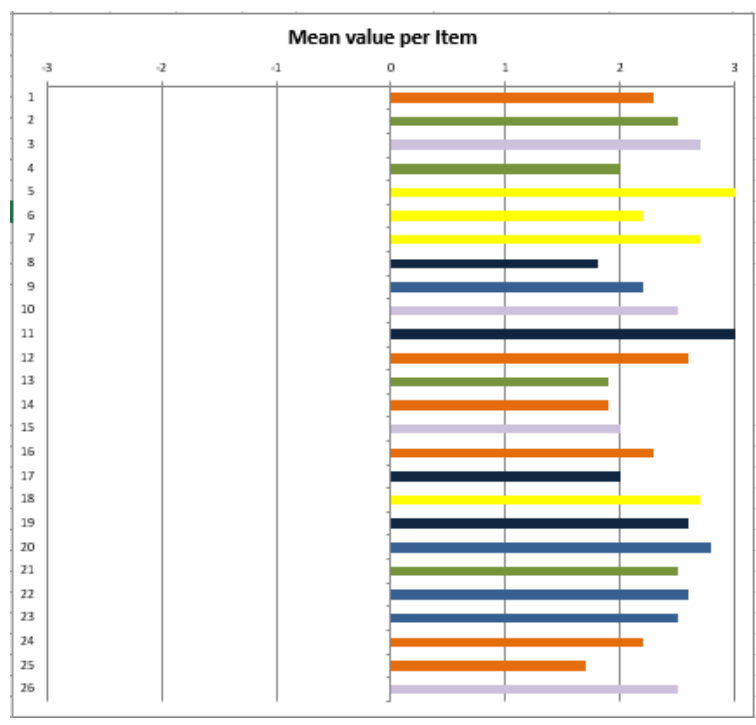

Gambar 19. Rata - Rata Impresi

Gambar 19 menunjukkan nilai ratarata setiap pertanyaan, dalam posisi negatif, nol, atau positif. Kemudian tabel Rata-Rata Impression Kelompok menunjukkan nilai rata-rata keseluruhan pertanyaan dilihat dari kelompoknya.

Tabel 4. Tabel Rata - Rata Impresi Kelompok

\begin{tabular}{|l|lc|}
\hline \multicolumn{2}{|c|}{ UEQ Scales } \\
\hline Daya tarik & ค 2.167 \\
\hline Kejelasan & ค 2.225 \\
\hline Efisiensi & ค 2.525 \\
\hline Ketepatan & ヤ 2.350 \\
\hline Stimulasi & ค 2.650 \\
\hline Kebaruan & ค 2.425 \\
\hline
\end{tabular}

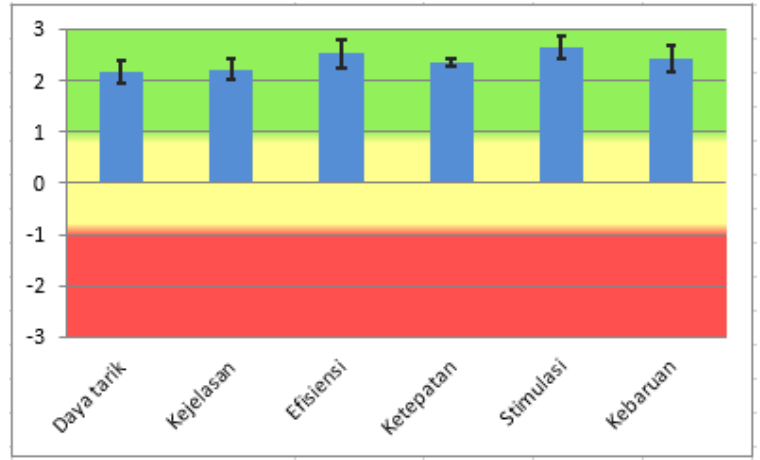

Gambar 20. Grafik Nilai Rata-Rata Impresi Kelompok 
Gambar 20 menunjukkan grafik nilai rata-rata pertanyaan sesuai kelompoknya. Nilai rata-rata impresi $>0.8$ merupakan nilai evaluasi positif, nilai rata-rata antara -0.8 dan 0.8 merupakan nilai evaluasi netral dan nilainilai < -0.8 merupakan evaluasi negatif. Sehingga dapat disimpulkan bahwa sistem Web Semantik Silsilah Keluarga Kawitan Pasek Gelgel cenderung memiliki impresi positif berturut-turut dalam kelompok Daya tarik, Kejelasan, Efisiensi, Ketepatan, Stimulasi, dan Kebaruan.

Tahap terakhir yaitu operation and maintenance yaitu penggunaan dan perawatan sistem yang bertujuan untuk mempermudah pengguna dalam mengoperasikan sistem untuk jikalau ada pengembangan selanjutnya dikemudia hari.

\section{SIMPULAN}

Berdasarkan paparan hasil perancangan, analisis, implementasi, pengujian, dan evaluasi sistem yang telah dilaksanakan pada penelitian ini maka dapat diambil kesimpulan sebagai berikut. (1) Sistem silsilah kawitan Pasek Gelgel dapat diintegrasikan dengan sistem lain dengan menggunakan RDF Schema pada bagian layer web semantik serta menggunakan metode pencarian forward chaining yang telah berjalan dengan baik . (2) uji respon pengguna mendapatkan hasil yang baik, yaitu setiap komponen yang ada dalam pertanyaan menunjukkan impresi yang positif dengan menunjukkan nilai ke arah angka 1 dan seterusnya. Adapun nilai ratarata impression setiap kelompok pertanyaan adalah Daya Tarik: 2.167; Kejelasan: 2.225; Efisiensi: 2.525; Ketepatan: 2.350; Stimulasi: 2.650; Kebaruan: 2.425. Sehingga dapat disimpulkan sistem Web Semantik Silsilah Keluarga Kawitan Pasek Gelgel layak untuk digunakan.

\section{REFERENSI}

[1] Sigit. (2013). Mengapa Bali Disebut Pulau Dewata. Retrieved from Astalog:

http://www.astalog.com/3157/menga pa-bali-disebut-pulau-dewata.htm (Diakses Pada 30 Januari 2018)
[2] Umardanny. (2017). Metode Forward Chaining dan Backward Chaining. Retrieved from http://umardanny.com/pengertianmetode-forward-dan-backwardchaining-sistem-pakar/

(Diakses Pada 30 Januari 2018)

[3] Soebandi, J. M. (1991). BABAD PASEK Jilid III. Denpasar: YAYASAN ADHI SAPTA KERTHI.

[4] Koivunen, R., \& Eric, M. (2001). W3C Semantic Web Activity. Retrieved from W3C: https://www.w3.org/2001/12/semwe b-fin/w3csw (Diakses Pada 30 januari 2018)

[5] W3C. (2013). SPARQL Query Results $X M L$ Format (Second Edition). Retrieved from W3C: https://www.w3.org/TR/rdf-sparqlXMLres/ (Diakses Pada 30 januari 2018)

[6] Arsani, W., Al', A. A., Nyimas, A., \& Mardiani. (2013). Penerapan Metode Forward Chaining Pada Aplikasi Sistem. URNAL 2007250106, 1-6.

[7] Rismadi, P. (2016). Memahami PHP dan MVC Pattern. Retrieved from Software Engineering: http://www.programming.smktaruna bhakti.net/blog/2016/03/31/memaha mi-php-dan-mvc-pattern/ (Diakses Pada 30 januari 2018)

[8] Galandi, F. (2016). Metode Waterfall : Definisi, Tahapan, Kelebihan dan Kekurangan. Retrieved from Pengetahuandanteknologi.com: http://www.pengetahuandanteknolog i.com/2016/09/metode-waterfalldefinisi-tahapan.html (Diakses Pada 30 Januari 2018) 